\title{
Coordination of Actors in The Application of Child- Friendly City in Sidoarjo District
}

\section{Koordinasi Aktor dalam Penerapan Kota Layak Anak di Kabupaten Sidoarjo}

\author{
Isnaini Rodiyah*, Roro Tantiko Dariyatun Nur Sanggito
}

Universitas Muhammadiyah Sidoarjo

\section{ABSTRACT}

This study aims to analyze and describe the Coordination of Actors in the Implementation of Child Friendly Cities in Sidoarjo Regency. This type of research is descriptive research with a qualitative approach, the research location is at the Office of Women's Empowerment, Child Protection and Family Planning. the research informant is the Head of the Fulfillment of Children's Rights. Types of primary and secondary data using data collection techniques through observation, interviews and documentation as well as literature study. The technical analysis of data uses an interactive model by Miles and Hubermen, namely by data reduction, data presentation, and drawing conclusions or verification. The results of the study indicate that the coordination of actors in implementing child-friendly programs is carried out through planning meetings, implementing activities in accordance with the roles and functions of each actor. Internal coordination is carried out by the regional Technical Implementation Unit (UPTD) in accordance with their respective task forces. Coordination is also carried out continuously until the activity evaluation stage, the results of the evaluation are also discussed in coordination meetings to determine the follow-up agenda for implementing child-friendly cities in the next

OPEN ACCESS ISSN 2338-445X (online) ISSN 2527-9246 (print) Edited by: Ilmi Usrotin Choiriyah Reviewed by: Ismi Dwi Astuti Nurhaeni and Sri Maryuni

*Correspondence: Isnaini Rodiyah Isnainirodiyah@umsida.ac.id Published: 29 September 2021

Citation:

Rodiyah I and Roro Tantiko Dariyatun Nur Sanggito(2021) Coordination of Actors in The Application of Child-Friendly City in Sidoarjo District.

JKMP(Jurnal Kebijakan dan

Manajemen Publik). 9:2.

doi: $10.21070 / j k m p . v 9 i 2.1579$ period. However, this coordination is still carried out at the level of government internal actors, while so far there has not been coordination with external institutions, both private and community actors.

Keywords: Coordination, Policy Implementing Actors, Child Friendly City

\section{PENDAHULUAN}

Anak adalah seseorang yang belum berusia delapan belas tahun, termasuk anak yang masih dalam kandungan. Kosnan berpendapat bahwa anak yaitu manusia muda dalam umur muda dalam jiwa dan perjalanan hidupnya karena mudah terpengaruh untuk keadaan sekitarnya. Kualitas anak juga sangat penting untuk ditingkatkan demi terciptanya sumber daya manusia yang berkualitas bagi bangsa dan negara di masa mendatang. Sumber daya manusia tidak berkualitas dengan pendidikan yang rendah serta lingkungan yang tidak kondusif akan memicu kasus-kasus kekerasan, ekspolitasi, diskrimanasi terhadap anak, dan semakin banyaknya anak yang terlibat kasus hukum (Kosnan, 2006).

Komitmen pemerintah Indonesia perlahan-lahan menciptakan dan menggencarkan pertumbuhan IDOLA (Indonesia Layak Anak) pada tahun 2030. Atas dasar hal tersebut, maka mulai diterapkannya kebijakan KLA (Kota Layak Anak) sejak tahun 2006. Hal 
tersebut tertuang dalam Peraturan Menteri Pemberdayaan Perempuan dan Perlindungan Anak Republik Indonesia Nomor 12 Tahun 2011 tentang indikator kebijakan kabupaten/kota layak anak. KLA sebagai suatu sistem pembangunan berbasis hak anakdi level kabupaten atau kota melalui pengintegrasian komitmen dan sumberdaya pemerintah, masyarakat dan dunia usaha yang terencana secara menyeluruh dan berkelanjutan dalam kebijakan dan kegiatan untuk menjamin terpenuhinya hak anak.

Kabupaten Sidoarjo sudah menyandang predikat sebagai KLA kategori Madya dan mendapatkan penghargaan sebanyak 6 kali berturut-turut. Menyandang predikat sebagai KLA merupakan sebuah kebanggaan dan sekaligus menjadi tantangan bagi Kabupaten Sidoarjo karena permasalahan anak di Kabupaten Sidoarjo belum teratasi dengan optimal. Berikut merupakan beberapa kasus permasalahan anak yang ada di Kabupaten Sidoarjo pada tahun 2018.

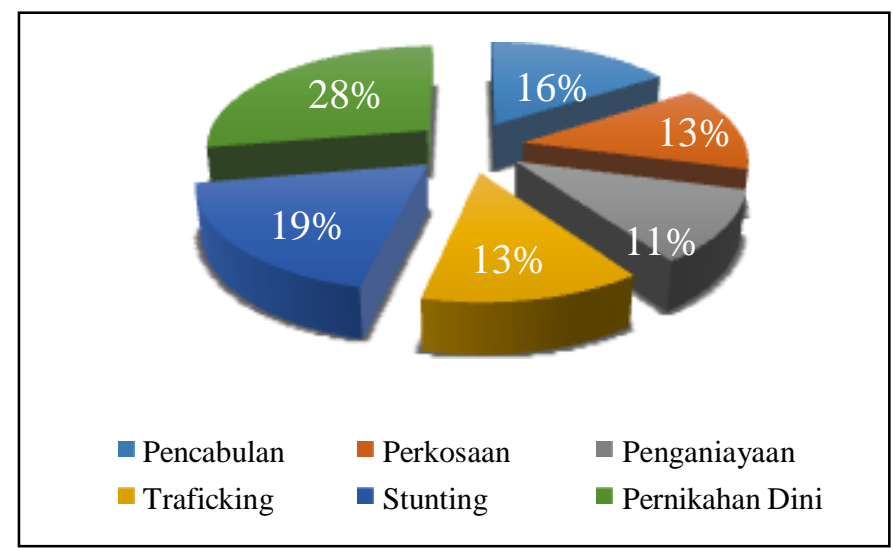

Gambar 1.1 Persentase Permasalahan Anak di Kabupaten Sidoarjo Tahun 2018

Berdasarkan pada gambar diatas yang bersumber dari Dinas P3AKB Kabupaten Sidoarjo di Tahun 2019 menyatakan bahwa sampai saat ini masih terdapat permasalahan terhadap anak di Kabupaten Sidoarjo yang masih belum teratasi dengan optimal. Seharusnya dengan diterapkan KLA Kabupaten Sidoarjo dapat mengurangi persentase permasalahan yang menimpa anak. Faktanya, bayangan itu hanya semu atau ilusi belaka karena seharusnya dalam hal tersebut sangat dibutuhkan koordinasi untukmenangani permasalahan salah satu indikator yang masih kurang. Seperti stunting, pernikahan dini, perkosaan, pencabulan, dan traficking.

Seharusnya dengan diterapkan KLA Kabupaten Sidoarjo dapat mengurangi permasalahan yang dihadapi anak. Faktanya, bayangan itu hanya ilusi belaka, karena kenyataannya masih ada yang kurang dalam koordinasi aktor yang terlibat dalam penerapan KLA seperti keterpaduan antar pemerintah pelaksana dengan pihak swasta masih diwarnai banyak masalah seperti sikap pihak swasta yang terkadang kurang bertanggungjawab pada kewajibannya sehingga menyebabkan keterlambatan penerimaan bantuan untuk penerapan KLA, antar aktor yang terlibat belum memahamkan satu visi dan tujuan, dan juga sikap dari anak ataupun pihak masyarakat yang acuh terhadap program pengembangan KLA.

Permasalahan pada anak di Kabupaten Sidoarjo seharusnya bisa dicegah dengan adanya koordinasi antar aktor yang telibat untuk pencapaian yang sangat memuaskan. Dengan koordinasi yang baik sebagai proses penyepakatan bersama sehingga di sisi yang satu semua kegiatan atau unsur itu terarah pada pencapaian suatu tujuan yang telah ditetapkan. Dengan diterapkannya Kota Layak Anak dengan koordinasi antar aktor yang terencana maka tingkat penerapannya akan semakin terlihat. Seperti pernyataan (Duadji, 2018) mengenai Kota Layak Anak Berbasis Collaborative Governance untuk untuk menciptakan koordinasi dengan kelembagaan khususnya dengan pihak swasta atau dunia usaha dapat dilihat dari tiga aspek antara lain tujuan yang jelas perumusan wewenang dan tanggung jawab yang jelas dan 
komunikasi yang dijalankan. Menurut Dewi Kartika Ratri (2014) bahwa Kebijakan Kota Layak Anak merupakan tanggung jawab bersama bukan hasil kerja satu instansi saja sehingga perlu koordinasi antara satuan kerja pemerintah daerah (SKPD) dengan SKPD lainnya.

Kenyataan di lapangan, sinergitas aktor yang terlibat dalam penerapan KLA, keterpaduan antara pemerintah dengan pihak swasta masih diwarnai banyak masalah seperti kurangnya koordinasi antar gugus tugas KLA, kurangnya koordinasi antar aktor baik dari pemerintah, demikian juga denganpihakswasta yang belum paham betul akan perannya dalam penerapan kota layak anak di Kabupaten Sidoarjo,halinidapatdilihatdarisikap pihak swasta yang terkadang kurang bertanggungjawab pada kewajibannya sehingga menyebabkan keterlambatan penerimaan bantuan untuk penerapan KLA. Selain dalam koodinasinya juga terdapat kurangnya komunikasi yang dilakukan oleh aktor yang terlibat menyebabkan terjadinya kesalahan dalam proses komunikasi yang menyebabkan tidak tercapainya tujuan yang hendak dicapai dalam penerapan KLA, antar aktor yang terlibat belum memahamkan satu visi dan tujuan, dan juga sikap dari anak ataupun pihak masyarakat yang acuh dan belum banyak mengetahui terhadap program pengembangan KLA.

Program Kota Layak Anak yang telah diinisiasi oleh pemerintah Kota menjadi salah satu kesempatan dalam upaya mewujudkan IDOLA (IndoneisaLayak Anak) dan mengidentifikasi persoalan anak yang selama ini sudah terlihat jelas maupun yang masih samar di tengah masyarakat. Berdasarkan pemaparan permasalahan di atas maka Penelitian ini diharapkan dapat mendeskripsikan koordinasi aktor dalam penerapan Kota Layak Di Kabupaten Sidoarjo.

\section{METODE PENELITIAN}

Jenis Penelitian yang digunakan peneliti dalam penelitian ini adalah jenis penelitian kualitatif dengan pendekatan diskriptif. Lokasi penelitian yang diambil berada di Kabupaten Sidoarjo dengan situs penelitian di Dinas Pemberdayaan Perempuan Perlindungan Anak Kabupaten Sidoarjo. Dalam penelitian ini yang menjadi fokus peneliti berdasarkan atribut koordinasi menurut Moekijat yaitu: (a) Hubungan langsung. (b) Kesempatan awal, (c) Kontinuitas koordinasi, (d) Dinamisme, (e) Tujuan yang jelas, (f) Organisasi yang sederhana, (g) Perumusan wewenang dan tanggungjawab yang jelas, (h) Komunikasi yang efektif, dan (i) Kepemimpinan yang efektif. Key informan dalam penelitian ini yaitu Kasi Pemenuhan Hak Anak Pada Dinas P3AKB. Sumber data diperoleh menggunakan tiga teknik pengumpulan data yaitu wawancara, observasi, dan dokumentasi. Sedangkan teknis analisis data menggunakan analisis data model interaktif oleh Miles dan Hubermen, yaitu dengan reduksi data, penyajian data, dan penarikan kesimpulan atau verifikasi .

\section{HASIL DAN PEMBAHASAN}

\section{Hubungan langsung}

Koordinasi dapat lebih mudah dicapai melalui hubungan pribadi langsung diantara orangorang yang bertanggung jawab. Sejalan dengan pendapat Pramono yang menyatakan bahwa suatu koordinasi dapat lebih mudah dicapai melalui hubungan pribadi secara langsung. Melalui hubungan pribadi langsung, ide-ide, cita-cita, tujuan-tujuan, pandangan-pandangan dapat dibicarakan dan salah paham dapat dijelaskan jauh lebih baik ketimbang melalui metode apapun lainnya (Pramono, Joko. Kinasih, 2019). Koordinasi antar aktor yang terlibat dalam penerapan Kota Layak Anak dilakukan dengan hubungan langsung yaitu melalui rapat koordinasi baik dari internal maupun eksternal yang dilakukan oleh Gugus Tugas KLA. Semua yang dilaksanakan oleh Gugus Tugas KLA berdasarkan aturan yang berpacu pada Undang-Undang Nomor 35 Tahun 2014 atas perubahan dari Undang-Undang Nomor 23 Tahun 2002 Tentang Perlindungan Anak dan aturan dari Kementerian Pemberdayaan 
Perempuan dan Perlindungan anak yang mengharuskan membentuk Gugus Tugas KLA. Dari dasar tersebut terbentuklah SK Bupati 188/83/438.1.1.3.2019/ tentang Gugus Tugas KLA. Gugus Tugas KLA melakukan rapat koordinasi secara langsung perklaster dari indikator KLA.

Dalam rapat koordinasi DinasPemberdayaan Perempuan Perlindungan Anak dan Keluarga Berencana bertugas memastikan aktor-aktor dalam Gugus Tugas KLA menyampaikan pendapatnya mengenai penerapan program ramah anak yang sudah diterapkan.Hubungan langsung yang dilakukan oleh Dinas Pemberdayaan Perempuan Perlindungan Anak dan Keluarga Berencana dengan pihak masyarakat atau anak, keluarga, dan juga pihak swasta yaitu dengan melakukan sosialisasi di desa-desa maupun kecamatan bahkan juga ke sekolahsekolah dan mengevaluasi kondisi kantin, jajanan dan UKS sekolah-sekolah yang ada Kabupaten Sidoarjo agar bisa menjadi sekolah yang ramah anak. Karena sekolah-sekolah yang ada di Kabupaten Sidoarjo belum seluruhnya ramah anak khususnya pada sekolah dasar.

Hal ini dapat dilihat dari sarana dan prasarana yang kurang mendukung kebutuhan anak. Dalam penerapan Sekolah Ramah Anak (SRA) pemerintah melakukan pendampingan dan pelatihan yang dilakukan oleh Dinas Pendidikan. Sedangkan hubungan langsung yang dilakukan oleh Dinas Pemberdayaan Perempuan Perlindungan Anak dan Keluarga Berencana dengan pihak swasta sudah dilakukan melalui koordinasi langsung dengan ketua CSR (Corporate Social Responcibility). Perusahaan-perusahaan yang sudah tergabung dengan Dinas P3AKB dalam menerapkan KLA sudah melaksanakan kegiatan peduli anak.Sudah banyak perusahaan memberi bantuan berupa beasiswa, memperbaiki sekolahsekolah, kegiatan-kegiatan yang responsif anak seperti lomba-lombadan melukis. Tetapi memang belum terinformasikan kepada Dinas $\mathrm{P} 3 \mathrm{AKB}$ danbelum terlaksana dengan maksimal.

\section{Kesempatan awal}

Koordinasi dapat dicapai lebih mudah dalam tingkat-tingkat awal perencanaan dan pembuatan kebijaksanaan. Misalnya, sambil mempersiapkan rencana itu sendiri, ada konsultasi bersama. Dengan cara demikian tugas penyesuaian dan penyatuan dalam proses pelaksanaan rencana lebih mudah. Untuk mendukung jalannya koordinasi perlu diciptakan perencanaan awal kegiatan yang dilakukan oleh aktor pelaksana program KLA di Kabupaten Sidoarjo. Koordinasi dilakukan dengan pihak intenal pemerintah maupun eksternal pemerintah, sebagaimana dijelaskan bahwa Perencanaan awal kegiatan perlu dilakukan koordinasi antar aktor (Dwinugraha, 2017). Koordinasi ini dilakukan untuk menetapkan pembentukan struktur organisasi pelaksana program KLA, menyusun aktoraktor yang terlibat dalam Gugus Tugas Kabupaten/Kota Layak Anak, dan membentuk Rencana Aksi Daerah Kabupaten/Kota Layak Anak yang disepakati oleh dinas-dinas terkait. Membentuk Gugus Tugas Kabupaten Layak Anak menjadi kesempatan awal dalam pelaksanaan koordinasi karena memang tugas dari Gugus Tugas KLA adalah mengkoordinasikan dan mensingkronisasikan pelaksanaan kebijakan pengembangan Kota Layak Anak di tingkat Kabupaten.

Tahap persiapan awal yang terjadi dalam penerapan KLS di Kabupaten Sidoarjo tersenut,diperkuat dalam Peraturan Menteri Pemberdayaan Perempuan dan Perlindungan Anak Republik Indonesia Nomor 13 Tahun 2011 Pasal 4 ayat 1 yang berbunyi tahap pengembangan KLA meliputi persiapan, peningkatan komitmen, pembentukan gugus tugas KLA, perencanaan terdiri dari penyusunan RAD KLA, pelaksanaan dan monitoring evaluasi. Struktur Gugus Tugas KLAsudah mencakup kelembagaan dan 5 (lima) klaster Kota Layak Anak.

\section{Kontinuitas koordinasi}

Menurut Tripathi dan Raddy (1983), koordinasi merupakan suatu proses yang kontinyu dan harus berlangsung pada semua waktu, mulai dari tahapan perencanaan. Oleh karena itu koordinasi merupakan dasar struktur organisasi, maka koordinasi harus berlangsung selama organisasi itu berfungsi. Kontinuitas koordinasi adalah 
suatu proses yang berlanjut dan harus berlangsung pada semua waktu mulai dari tahap perencanaan awal sampai dengan tahap evaluasi yaitu dilakukan secara terus menerus dan berkelanjutan dalam penerapan Kota Layak di Kabupaten Sidoarjo (Triana Rahmawati, Irwan Noor, 2014).

Dalam menciptakan koordinasi yang optimal diperlukan kontinuitas koordinasi yang merupakan suatu proses yang berlanjut dan harus berlangsung pada semua waktu mulai dari tahap perencanaan awal, rapat koodinasi dalam penerapan Kota Layak Anak di Kabupaten Sidoarjo sampai dengan tahap evaluasi. Rapat koordinasi yang dilakukan dalam penerapan Kota Layak Anak dilakukan secara berkesinambungan tidak hanya berhenti pada terlaksananya program-program yang ramah anak. Setelah program-program ramah anak terlaksana maka harus dilakukan kembali rapat koordinasi untuk menyampaikan hasil capaian-capaian dalam penerapan program ramah anak kepada Dinas Pemberdayaan Perempuan Perlindungan Anak dan Keluarga Berencana untuk dimasukkan kedalam data monitoring evaluasi.

\section{Dinamisme}

Koordinasi harus secara terus menerus diubah mengingat perubahan lingkungan baik internal maupun eksternal. Sebagaimana dijelaskan dalam (Triana Rahmawati, Irwan Noor, 2014) bahwa koordinasi harus secara terus menerus diubah mengingat perubahan-perubahan lingkungan intern maupun ekstern. Dengan kata lain koordinasi itu jangan kaku. Koordinasi akan meredakan masalah-masalah yang timbul. Koordinasi yang baik akan mengatasi masalah secara dini dan mencegah kejadiannya. Dalam penerapan Kota Layak Anak di Kabupaten Sidoarjo untuk kebijakan dan struktural memang dilakukan perubahan karena mengikuti perkembangan zaman. Perubahan tersebut dilakukan mengingat saat ini perluadanya modernisasi agar dapat memberikan pelayanan dan perlindungan terbaik kepada anak. Kota Layak Anak harus menyesuaikan dan terus berkembang karena dengan mengikuti perkembangan zaman maka akan mempermudah setiap aktivitas pekerjaan dalam menerapkan program-program ramah anak dan juga dapat membuat perubahan yang lebih baik dalam menerapkan Kabupaten/Kota Layak karena memang sangat kompleknya membentuk suatu Kabupaten menjadi Kabupaten Layak Anak.

\section{Tujuan yang jelas}

Tujuan dalam penerapan Kota Layak Anak di Kabupaten Sidoarjo adalah menjadikan sebuah kabupaten menjadi kabupaten yang responsiv dan ramah anak dengan seluruh sistem kondusif dan semua aktor yang sigap. Salah satu cara mencapai tujuan utama dari Kabupaten/Kota Layak Anak yaitu dengan penyebaran tanggung jawab yang jelas dalam penerapan Kota Layak Anak di Kabupaten Sidoarjo melalui pembentukan Gugus Tugas Kabupaten/Kota Layak Anak. Gugus Tugas Kabupaten/Kota Layak Anak dalam melaksanakan tanggung jawab yaitu dengan memperhatikan 5 (lima) kluster hak anak yang harus terpenuhi sistemnya di kabupaten atau kota yang menerapkan Kota Layak Anak.

Upaya pemerintah dalam menyiapkan dan menciptakan kabupaten atau kota responsif anak di Kabupaten Sidoarjo, caranya yaitu dengan adanya sistem ruteaman, nyaman, selamat dari dan ke sekolah. Hal tersebut merupakan tanggungjawab Dinas Pemberdayaan

Perempuan Perlindungan Anak dan Keluarga Berencana serta POLRESTA Sidoarjo untuk menciptakan jalan yang responsif anak. Jumlah rute aman, nyaman, selamat dari dan ke sekolah setiap tahunnyameningkat meskipun masih baru diciptakan. Karena memang peran aktif dan tanggung jawab dari beberapa OPD dan POLRESTA Sidoarjo dalam menekanangka kecelakaan di jalan raya melalui program save our student, safety riding milenial, dan rambu-rambu lalu lintas penyebrangan di dekat sekolah.

Dalam menciptakan tujuan dari penerapan Kota Layak Anak tidak luput dari keikutsertaan anak sebagai pelaku utama dalam kegiatan ramah anak yang digencarkan oleh pemerintah. Salah satu kegiatan dari keikutsertaan anak dalam kegiatan KLA adalah adanya Forum Anak. Forum anak yaitu sebuah perkumpulan anak yang terdiri dari anak berusia 0-18 tahun yang bertempat tinggal di wilayah setempat. Forum anak merupakan sebuah forum yang menampung dan menyalurkan aspirasi anak, mensosialisasikan program ramah anak melalui 
media-media sosial yang dimiliki, dan melaporkan ke Dinas Pemberdayaan Perempuan Perlindungan Anak dan Keluarga Berencana. Saat ini forum anak hanya terbentuk pada tingkatan kabupaten tetapi nantinya akan ada utusan dari kecamatan. Dinas Pemberdayaan Perempuan Perlindungan Anak dan Keluarga Berencana pada tahun 2018 sudah membentuk 6 (enam) forum anak dan akan dibentuk 12 (dua belas) forum anak pada tahun 2019-2020.

\section{Organisasi yang sederhana}

Penerapan Kabupaten/Kota Layak Anak di Kabupaten Sidoarjo struktur organisasi sudah sangat sederhana sesuai dengan apa yang dibutuhkan dalam menerapkan Kabupaten/Kota Layak Anak di Kabupaten Sidoarjo dan memudahkan dalam melakukan koordinasi. Sebagaimana dijelaskan Moekijat bahwa Struktur organisasi yang sederhana memudahkan koordinasi yang efektif. Struktur organisasi dalam Gugus Tugas KLA dibentuk berdasarkankebutuhan yang akan diselenggarakan oleh pemerintah dalam menerapkan Kota Layak Anak di Kabupaten Sidoarjo (Moekijat, 1994). Semua aktor yang terlibat dalam GugusTugas KLA sudah mampu berkomitmen dalam pelaksanaan kewajibannya hanya saja terkadang masih sukar dalam penyatuan visi dan misi yang akan dilaksanakan. Karena terkadang masih banyak aktor pemerintah yang belum mengetahui tentang penerapan Kota Layak Anak di Kabupaten Sidoarjo.

\section{Perumusan wewenang dan tanggungjawab yang jelas}

Koordinasi juga membutuhkan perumusan wewenang dan tanggungjawab yang jelas agar memudahkan tercapainya koordinasi yang sempurna dalam penerapan suatu program atau kegiatan. Menurut Lovenda, pendelegasian wewenang dan tanggung jawab berpengaruh terhadap efektivitas kerja pegawai (Lovenda, 2019). Wewenang yang jelas tidak hanya mengurangi pertentangan diantara pegawai-pegawai yang berlainan, tetapi juga membantu mereka dalam pelaksanaan pekerjaan dengan kesatuan tujuan. Selanjutnya, wewenang yang jelas membantu manajer dalam mengawasi bawahan bertanggung jawab atas pelanggaran pembatasan-pembatasan. Dalam penerapan Kabupaten/Kota Layak Anak perumusan wewenang dan tanggungjawab yang jelas akan mengurangi pertentangan diantara pegawaipegawai dan juga membantu dalam pekerjaan. Perumusan wewenang dalam penerapan Kota Layak Anak sudah bersifat formal dan dapat dilaksanakan secara efektif oleh para aktor yang terlibat.

Semua aktor yang terlibat melakukan wewenang dan tanggung jawab sesuai dengan prosedur dari Gugus Tugas KLA. Semua aktor yang terlibat tidak bisa terpisah satu dengan yang lainnya semua saling ketergantungan dan saling membutuhkan satu sama lain. Sebagaimana contoh dalam wewenang dan tanggung jawab yaitu adanya lembaga konsultasi bagi orang tua dan anak. Untuk lembaga konsultasi orang tua, anak atau keluarga berada di Dinas Sosial. Selain terdapat pada DinasSosial lembaga konsultasi bagi orang tua dan anak juga ada di Mal Pelayanan Publik Sidoarjo (PUSYANGATRA), Konsultasi Psycologi di RSUD, danKonsultasi keluarga pada UPTD PPA. Semua lembaga penyelenggara telah dilatih melalui rapat koordinasi, penguatan jaringan atau kader baik di tingkat provinsi maupun kabupaten.

\section{Komunikasi yang efektif}

Komunikasi yang efektif merupakan salah satu persyaratan untuk koordinasi yang baik. Dalam penerapan KLA di Kabupaten Sidoarjo komunikasi yang terjalin antar aktor yang terlibat sudah sangat mampu menerima dan merespon dengan sangat baik. Tetapi masih ada beberapa aktor yang belum bisa menyampaikan informasi yang terkait dengan KLA. Koordinasi dapat dibangun dengan melibatkan sektor swasta, tokoh masyarakat, tokoh adat, pemerintah kota dari masing-masing departemen atau sektor, lembaga non pemerintah, dan masyarakat sipil melalui komunikasi yang efektif. Sinergitas yang terbangun dapat saling berintegrasi dan bersinergi menjadi suatu kesatuan yang saling mengisi dan membutuhkan satu dengan lainnya. 


\section{Kepemimpinan yang efektif}

Kepemimpinan yang efektif menjamin koordinasi kegiatan orang-orang, baik pada tingkat perencanaan maupun pada tingkat pelaksanaan. Kepemimpinan tersebut terjalin dalam pemberian instruksi dalam penerapan KLA. Pemberian instruksinya mulai dari pemimpin dinas sendiri sampai dengan pimpinan dari Gugus Tugas Kabupaten/Kota Layak Anak diberikan sangat jelas. Sebagaimana dijelaskan dalam Kuntjoro bahwa Kepemimpinan yang efektif merupakan metode koordinasi yang paling baik dan tidak ada lain yang dapat menggantikannya (Kuntjoro, 2020).

\section{KESIMPULAN}

Koordinasi aktor dalam penerapan Kota Layak Anak di Kabupaten Sidoarjo pada indikator hubungan langsung dilakukan oleh Dinas Pemberdayaan Perempuan Perlindungan Anak dan Keluarga Berencana dengan pihak swasta sudah dilakukan melalui koordinasi langsung dengan ketua CSR (Corporate Social Responcibility). Indikator kesempatan awal dilakukan melalui rapat koordinasi dengan membentuk struktural, menyusun aktor-aktor yang terlibat dalam Gugus Tugas Kabupaten/Kota Layak Anak, dan membentuk Rencana Aksi Daerah Kabupaten/Kota Layak Anak yang disepakati oleh dinas-dinas terkait. Indikator kontinuitas koordinasi dilakukan dengan rapat koordinasi secara berkesinambungan tidak hanya berhenti pada terlaksananya program-program yang ramah anak. Setelah program-program ramah anak terlaksana maka harus dilakukan kembali rapat koordinasi untuk menyampaikan hasil capaian-capaian. Pada indikator dinamisme diperlukan perubahan kebijakan dan struktural karena mengikuti perkembangan zaman. Perubahan tersebut dilakukan mengingat saat ini perlu adanya modernisasi agar dapat memberikan pelayanan dan perlindungan terbaik kepada anak.

Indikator tujuan yang jelas dalam penerapan Kota Layak Anak di Kabupaten Sidoarjo adalah menjadikan sebuah kabupaten menjadi kabupaten yang responsif dan ramah anak dengan seluruh sistem kondusif dan semua aktor yang sigap. Salah satu cara mencapai tujuan yaitu melalui pembentukan Gugus Tugas Kabupaten/Kota Layak Anak. Indikator organisasi yang sederhana yaitu struktur organisasi dalam Gugus Tugas KLA dibentuk berdasarkan kebutuhan yang akan diselenggarakan oleh pemerintah dalam menerapkan Kota Layak Anak di Kabupaten Sidoarjo. Indikator wewenang dan tanggung jawab yang jelas yaitu adanya lembaga konsultasi bagi orang tua dan anak. Untuk lembaga konsultasi orang tua, anak atau keluarga berada di Dinas Sosial. Indikator komunikasi efektif dalam penerapan KLA di Kabupaten Sidoarjo terjalin antar aktor yang terlibat sudah sangat mampu menerima dan merespon dengan sangat baik. Serta indikator kepemimpinan yang efektif terjalin dalam pemberian instruksi dalam penerapan KLA. Pemberian instruksinya mulai dari pemimpin dinas sendiri sampai dengan pimpinan dari Gugus Tugas Kabupaten/Kota Layak Anak diberikan sangat jelas.

\section{PENDANAAN}

Publikasi artikel ini menggunakan dana pribadi dari penulis.

\section{UCAPAN TERIMA KASIH}

Pertama-tama kami ucapkan terima kasih atas kepada civitas akademika Universitas Muhammadiyah Sidoarjo atas dukungannya sehingga artikel kami dapat di publish di Jurnal Kebijakan dan Manajemen Publik. 


\section{REFERENCES}

Abdi, Reni Bandari. 2014. Implementasi Kebijakan Pengembangan Kabupaten/Kota Layak Anak (KLA) di Kota Tangerang Selatan. Skripsi, (online). Oktober 2014 Arifin, Syamsul. 2016. Kota Layak Anak Berbasis Kesehatan. Berkala Kedokteran. (online). Vol. 12, No.1 Halaman: 117-122, Februari 2016

Ayom, 2011, 30 Juni. Kota Layak Anak Untuk Siapa. (Online). (https://komnaspa.wordpress.com/2011/07/01/kotalayak-anak-untuk-siapa/, diakses 12 Agustus 2019)

Dimyati, Vien, 2016, 21 Maret. Sederet Syarat Mewujudkan Kota Layak

Anak. (Online).(https://lifestyle.okezone.com/read/2016/03/21/ 196/1342101/sederet-syarat-mewujudkan-kota-layakanak, diakses 12 Agustus 2019)

Duadji, N. (2018). Kota Layak Anak Berbasis Collaborative Governance. 13(1), 1-22.

Dwinugraha, A. P. (2017). Sinergitas Aktor Kepentingan Dalam Penyelenggaraan Pemerintahan Desa (Studi pada Desa Urek-Urek Kecamatan Gondanglegi Kabupaten Malang). PUBLISIA (Urnal Ilmu Administrasi Publik), 2(1), 1-7.

Elizabeth, Andriani., Zainal Hidayat. 2016. Implementasi Program Kota Layak Anak Dalam Upaya Pemenuhan Hak-Hak Anak di Kota Bekasi. Jurnal Manajemen Kebijakan Publik. (online).

Fatimah, Siti. 2018. Sinergitas Aktor Pelaksana Dalam Penyelenggaraan Parkir Berlangganan Di Kabupaten Sidoarjo. Skripsi. Universitas Muhammadiyah Sidoarjo.

Himawati, Ika. Dkk. 2018. Analisis Pemenuhan Hak Dasa Anak Pada Program "Kota Layak Anak" di Kecamatan Gading Cempaka Bengkulu. Jurnal Ilmu Sosial Mamangan. (online). Vol. 5, No.1, Januari-Juni 2016. KLA, 2017, 29 Maret. Kajian Kabupaten Sidoarjo Layak Anak 2008. (online). (https://www.kla.id/kajiankabupaten-sidoarjo-layak-anak-2008/, diakses 12 Agustus 2019).

KLA, 2017, 29 Maret. Kajian Kabupaten Sidoarjo Layak Anak 2008. (online). (https://www.kla.id/kajiankabupaten-sidoarjo-layak-anak-2008/, diakses 12 Agustus 2019)
Kuntjoro, B. T. (2020). Keberadaan Forum Koordinasi Kepemimpinan (Forkopimda) Pada Sistem Pemerintah Daerah Di Kabupaten Tanah Datar. Unes Law Review, 2(4), 466-477.

Lovenda, E. 2019. Pengaruh Pendelegasian Wewenang dan Tanggung Jawab Terhadap Efektivitas Kerja Pegawai pada Dinas Kesehatan Provinsi Sumatera Utara. http://repository.uma.ac.id/handle/123456789/10728

Miles, B. Mathew dan Michael Huberman. 1992. Analisis Data Kualitatif Buku Sumber Tentang Metodemetode Baru. Jakarta: UIP.

Moekijat.1994. Koordinasi : Suatu Tinjauan Teoritis, Penerbit Mandar Maju :Bandung.

Nasukah, B., Sulistyorini, S., \& Winarti, E. (2020). Peran Komunikasi Efektif Pemimpin Dalam Meningkatkan Kinerja Institusi. Al-Tanzim: Jurnal Manajemen Pendidikan Islam, 4(1), 81-93.

Pramono, J., \& Kinasih, W. 2019. Sinergitas antar stakeholder dalam penyelengaraan kamtibmas di Kelurahan Gilingan Kecamatan Banjarsari Kota Surakarta. Research Fair Unisri, 3(1).

Rahmawati, T. (2014). Sinergitas Stakeholders dalam Inovasi Daerah (Studi pada Program Seminggu di Kota Probolinggo (SEMIPRO)). Jurnal Administrasi Publik, 2(4), 641-647.

Conflict of Interest Statement: The authors declare that the research was conducted in the absence of any commercial or financial relationships that could be construed as a potential conflict of interest

Copyright (C) 2021 Isnaini Rodiyah and Roro Tantiko Dariyatun Nur Sanggito. This is an open-access article distributed under the terms of the Creative Commons Attribution License (CC BY). The use, distribution or reproduction in other forums is permitted, provided the original author(s) and the copyright owner(s) are credited and that the original publication in this journal is cited, in accordance with accepted academic practice. No use, distribution or reproduction is permitted which does not comply with these terms. 